DOI: 10.30519/ahtr.929800

Advances in Hospitality and Tourism Research (AHTR)

\title{
COVID-19, WINE ROUTES, CRISIS MANAGEMENT AND RESILIENCE AMONGST RURAL WINE TOURISM BUSINESSES
}

\author{
Elisabeth KASTENHOLZ ${ }^{1}$ \\ Department of Economics, Management, \\ Industrial Engineering and Tourism, \\ University of Aveiro, Portugal \\ ORCID: 0000-0003-4700-0326
}

\author{
Diana CUNHA \\ Department of Economics, \\ Management, Industrial Engineering \\ and Tourism, University of Aveiro, \\ Portugal \\ ORCID: 0000-0001-8338-6647
}

\author{
Conceição CUNHA \\ Department of Economics, \\ Management, Industrial Engineering \\ and Tourism, University of Aveiro, \\ Portugal \\ ORCID: 0000-0001-8797-549X
}

\author{
Cristina \\ BARROCO \\ Polytechnic Institute of \\ Viseu, Portugal \\ ORCID: 0000-0003-3016- \\ 8763
}

\author{
Andreia \\ PEREIRA \\ University of Coimbra $\mathcal{E}$ \\ Polytechnic Institute of \\ Viseu, Portugal \\ ORCID: 0000-0001-8765- \\ 6608
}

\author{
Maria João CARNEIRO \\ Department of Economics, \\ Management, Industrial \\ Engineering and Tourism, \\ University of Aveiro, Portugal \\ ORCID: 0000-0002-1682-6857
}

\author{
Bernard LANE \\ EURAC Research, Centre \\ for Advanced Studies, \\ Bolzano-Bozen, Italy \\ ORCID: 0000-0002-0939- \\ 3897
}

\begin{abstract}
This paper addresses the impacts of the COVID-19 pandemic on wine route related rural tourism along two Portuguese wine routes, as perceived by agents of supply on those routes. Discourses from 47 interviews are subjected to content analysis, considering impact perception and crisis management approaches. The results highlight COVID-19's impacts on wine tourism businesses, including financial losses, negative emotions and systemic effects, the latter illustrating the chain of adverse effects caused by COVID-19. Many uncoordinated strategies employed to cope with the pandemic are noted. The research suggests that perceived impacts of COVID-19 relate to business profiles, to the regional context, to the stage of the crisis and specific strategies adopted. The theoretical and practical implications for future tourism management, especially in the context of wine and rural tourism, as well as sustainable tourism, are discussed, including the need for social capital creation, partnership work and product development through innovation.
\end{abstract}

\author{
Article History \\ Received 30 April 2021 \\ Revised 25 August 2021

\section{Keywords \\ COVID-19 \\ wine tourism \\ rural tourism \\ impact perceptions \\ supply agents \\ crisis management}

Accepted 14 September 2021

Published online 16 Dec. 2021

\footnotetext{
${ }^{1}$ Address correspondence to Elisabeth Kastenholz (PhD), Department of Economics, Management, Industrial Engineering and Tourism (DEGEIT) of University of Aveiro (UA) and the Research Unit on Governance, Competitiveness and Public Policies (GOVCOPP), Portugal. E-mail: elisabethk@ua.pt
} 


\section{INTRODUCTION}

As this paper was being written, tourism was and is in crisis. Many commentators expect the COVID-19 pandemic to change whole societies and their economies totally. Margaret MacMillan, historian and professor at the Universities of Oxford and Toronto, writing in May, 2020 said: "the pandemic is a turning point in history. The crisis exposes our weaknesses. Will our leaders choose reform or calamity?" (MacMillan, 2020).

How might tourism be affected? Will progress towards more sustainable forms of tourism stop or accelerate? Will some forms of tourism be affected more than others? Gössling et al. (2021) give early reactions to many tourism and COVID-19 issues based on published sources. Nevertheless, no research was found that addresses explicitly how relevant specific forms of tourism such as wine and rural tourism are affected by, or react, to that crisis. This paper looks at new, specific, and detailed research on crisis management by tourism providers on two wine routes in rural Portugal, assessing the impacts they felt, their "real world" reactions, the implications for other wine routes, and for rural tourism in general, regarding COVID-19 and other potential crises.

\section{LITERATURE REVIEW}

\section{COVID-19 - Risks and Resilience}

COVID-19, a new type of coronavirus, with high rates of propagation even before diagnosis, began in China, apparently in December 2019 and quickly spread worldwide (WHO, 2020a). With case numbers increasing exponentially, on March 11th 2020, the World Health Organization declared it a pandemic affecting the whole world population (WHO, 2020b). As its spread accelerated, jeopardizing public health systems, measures were put in place to prevent its propagation. In many countries, mandatory "lockdowns" "2" were decreed, and borders closed (Gössling et al., 2021). With many public spaces and businesses closed, there were severe immediate repercussions, such as rising unemployment (Forbes, 2020). Social distancing became the new responsible behaviour, together with using facemasks, sanitisers, and disinfectants. (WHO, 2020c).

\footnotetext{
2 The term "lockdown" refers to periods when the state seriously restricts activities, typically including non-essential travel, staying overnight in accommodation other than your own, going to bars and restaurants, closing non-food shops, entertainment, etc.
} 
The prophylactic measures taken by many countries have had abrupt economic impacts: markets have stalled, enterprises have gone bankrupt, an unprecedented global economic recession is predicted, with rising unemployment (Statista, 2020a). This situation is aggravated in countries and regions that have economies that primarily rely on tourism (Statista, 2020b). Global tourism revenues could fall by around 20\% (Statista, 2020c), requiring new resilience strategies amongst tourism stakeholders.

\section{Crisis Management in Tourism}

According to Blake and Sinclair (2003), tourism demand is susceptible to security and health concerns. The pandemic highlights the urgent need for widespread strategic action to prepare for future threats to health, tourism, and social well-being (Jamal \& Budke, 2020).

'Crisis management' is well researched in the tourism literature. It is based on coping with situations that are unwanted, unpredicted, extraordinary, and almost uncontrollable, instigating widespread disbelief and discomfort (Rosenthal et al., 1989). COVID-19 is clearly a tourism crisis for all forms of tourism, including wine and rural tourism, as discussed below. It also has increasing relevance for the concept of sustainable tourism.

Most tourism crisis management models are influenced by Mitroff's model classifying organizations as either 'crisis prone' or 'crisis prepared' (Pearson \& Mitroff, 1993). Mitroff's model has six stages: signal detection, preparation, prevention, containment (damage limitation), business recovery, learning and redesign. The tourism literature is more concerned with emergent crises and takes a resource-based approach, focusing on personnel training, equipment, and crisis response planning (Paraskevas \& Quek, 2019).

Risk, the quantified expression of an organization's vulnerability to hazards/ threats, refers to potential future crises, "whereas a crisis occurs now, is characterized by ambiguity of cause, effect and means of resolution and necessitates immediate action" (Paraskevas \& Quek, 2019, p. 420). Risk and crisis management are complementary learning-based stages that seek to limit the consequences of disruption and then bring recovery. This capacity - referred to as "resilience" - is "a function of an organization's overall situation awareness, management of keystone vulnerabilities and adaptive capacity in a complex, dynamic and interconnected environment" (McManus et al., 2008, p.82). Cartier and Taylor (2020) argue that a 
destination's resilience depends on decision-making practices surrounding the reduction of disaster impacts, involving all destination stakeholders. Recovery depends on a holistic view of how economic losses are minimized without compromising a region's natural and human resources. A crisis can, however, despite losses, also be an opportunity to gain resilience through wise "post-disaster reconstruction", involving new tourism enterprises, management, projects and enhanced social capital (Nian et al., 2019). Resilience in tourism destinations, making them more capable of handling crises, could imply significant changes in: (1) tourism facilities, services, and infrastructure; (2) environmental and cultural tourism resources; (3) tourist markets; and (4) skilled employees (Lew, 2014).

Success depends on timely communication, creating a collective community spirit, and support for future disaster management activity plans at the community level (Cartier \& Taylor, 2020). A community's resilience thus reflects on its ability to adapt collectively to catastrophes, which positively correlates with its post-catastrophe recovery and transformation, and a destination's ability to handle successfully impacts and stress related events (Tsao \& Ni, 2016).

A crisis precipitates complex, changing situations where standard rules of action for the organization are suspended and other tasks take priority. Laws et al. (2007) write that crisis solutions may involve the entire community, other organizations, and government agencies, each having their ways of operating and set of priorities. This complex managerial environment calls for destination coordination and a common future vision, i.e., strong whole destination governance (Laws et al., 2007).

Policymakers are confronted with three central issues relevant to any downturn in tourism activity (Blake \& Sinclair, 2003): (a) whether the downturn is sufficiently large to merit offsetting measures; (b) the duration of the downturn; and (c) choice of recovery policies and their implementation. In their study of the September 11 terrorist attacks, Blake and Sinclair (2003) concluded that sector-specific targeted subsidies and tax reductions were the most effective in handling the crisis, policies which perhaps are also appropriate for the COVID-19 crisis.

Previous research on health crisis management in tourism, related to COVID-19 or diseases such as SARS (Henderson, 2004; Kim et al., 2005) shows that tourism businesses may have to: cancel activities; take special measures concerning human resources (e.g. unpaid leaves); adopt hygiene measures (e.g. face masks); ensure social distancing (e.g. placing tables further apart); adopt other measures (e.g. taking visitor temperatures); train 
staff; focus on domestic markets and lower prices. It also highlights the need to redesign marketing strategies (e.g. developing joint marketing campaigns), transmit confidence to visitors (e.g. through safety certificates) and develop coordinated actions with other organisations. Some research concerning COVID-19, mainly research agendas or summaries of guidelines (e.g. Sigala, 2020; Zenker \& Kock, 2020), also suggest that some of these strategies, such as staff training and coordinated action, as well as relying more on online and social media promotion, will be important approaches in this pandemic period. However, there are, so far, few studies that identify the strategies adopted by tourism supply agents in this crisis. This is especially true for wine tourism and associated types of rural tourism.

\section{Wine Tourism in Crisis? Challenges and Opportunities}

Anecdotal, but un-researched, evidence from rural tourism destinations in Europe suggests that most forms of rural tourism could be relatively unaffected in the long term by COVID-19. Rural tourism activities walking, climbing, horse riding, bird watching, farm visits, etc, are outdoors (Lane, 1994, 2020), reducing perceived risks of infection, compared to large resorts and crowded cities.

Wine tourism is a form of rural tourism involving visits to wineproducing areas and to attractions such as wineries and wine-related events; wine is, the, or one of the main motivations for the rural visit (Charters \& Ali-Knight, 2002; Hall et al., 2000). More holistic rural wine tourism experiences are sometimes conceptualized as "Terroir Tourism" (Holland et al., 2017). Wine tourism, and wine routes, have strong roles in sustainable rural development, benefiting not just wine producers but also many other economic, social, and cultural rural activities (Guedes \& Joukes, 2015; Pellin \& Vieira, 2015).

From a supply-side perspective, wine tourism focus on activities increasing wine sales, especially in European countries with long wine traditions. Wine tourism, like many other forms of rural tourism, is a diversification and sustainable development tool (Correia et al., 2014). Many producers still consider the wine business their primary activity, with wine tourism creating a useful promotional or branding effect (Bruwer et al., 2013). During the pandemic crisis, with social distancing and mobility constraints, the provision of wine tourism activities, particularly those taking tourist groups with close contact between winery staff and travellers, probably required numerous safety measures. Some producers, therefore, closed their tourism activities and focused on wine production. Others say 
that, in certain circumstances, even during the pandemic, new tourism opportunities may arise, paying off in the post-COVID-19 future. Nevertheless, further research is needed to provide a full understanding of: (a) the challenges brought to rural wine tourism businesses and territories by the constantly changing COVID-19 context; (b) longer-term market trends in tourism that may be stimulated by today's restrictions and redefinitions of tourism and lifestyles in general and (c) other potential benefits and reforms.

Some rural wine terroir visitors' motivations may, indeed, present a search for a distinct type of tourism, a quest for unique, personalized experiences in rural, non-crowded territories, with opportunities to escape and make contact with nature, enjoying beautiful landscapes (Carneiro et al., 2015; López-Guzmán et al., 2014; Quadri-Felitti \& Fiore, 2012; Ye et al., 2017). Additionally, an increasing search for the local and particular, rather than the global and standardized, associated with the quest for authenticity, is visible in tourism in general (Kastenholz, 2018) and food tourism in particular (Sidali et al., 2015). This trend also relates to 'slow tourism', the search for locally shaped, 'authentic' tourist experiences enjoyed sincerely and slowly (Oh et al., 2016).

Although tourism demand is suffering greatly from COVID-19, many individuals may feel the urge to travel again, and (see earlier), that may favour rural wine tourism destinations as safe non-congested places that offer contact with nature. The risks associated with wine tourism in a pandemic scenario differ according to the activities offered. Indoor activities, such as winery or wine museum visits (Quadri-Felitti \& Fiore, 2012) demand carefully demarcated social distancing, but outdoor activities such as walking or cycling through vineyards (Quadri-Felitti \& Fiore, 2012) imply much less risk. Some activities, like tasting wines, having a meal in a winery and participating in winemaking activities (e.g. López-Guzmán et al., 2014; Quadri-Felitti \& Fiore, 2012; Ye et al., 2017), bring particular challenges since visitors touch and manipulate products, equipment, and objects. There is also a strong social element because of the highly appreciated direct contacts with winemakers (Bruwer \& Rueger-Muck, 2019): specific visitor management measures are required. Furthermore, a wine tourism trip may include activities in different places managed by different suppliers; the pandemic may require enhanced supplier/ network coordination to ensure safe experiences, essential for the entire destination and its image. The empirical research in this paper provides a deeper analysis of these issues as seen by suppliers coping with the crisis. The findings below explore what is probably the first detailed research evidence 
of the impacts of COVID-19 felt by businesses working in wine tourism in rural areas and the strategies adopted to deal with these impacts.

\section{MATERIALS AND METHODS}

This study uses data collected during a research project on wine tourism experiences in rural areas, specifically data from two wine routes in Central Portugal, the Bairrada Region (between Aveiro and Coimbra) and the Dão Region (near Viseu). The project ${ }^{3}$ comprehensively studies facets of the rural wine tourism experience, as co-created by supply, communities and markets, living and sharing such experiences, considering views from all stakeholders involved.

Data were collected and analysed using ongoing in-depth interviews with wine tourism suppliers. Wine route stakeholders interviewed for this paper included wine producers offering traditional wine tasting, selling and winery tours, accommodation unit owners, restaurant managers, tour operators/ agents and companies with two or more of these business types. In total, 47 interviews were done, 24 on the Dão route and 23 on the Bairrada route. Most interviewees $(n=33)$ were interviewed during the lockdown and 14 were done post lockdown. Qualitative data collection was particularly suitable for this study to: (a) obtain rich in-depth information regarding the development of relatively recent activities and innovative approaches in emerging wine tourism destinations; (b) understand the perception of complex and subjectively lived wine tourism experiences and dynamics from the perspectives of agents of supply; and very particularly (c) assess the perceptions and intentions of tourism suppliers now facing an unforeseen, hard-to-manage crisis (Mohajan, 2018).

After assessing the profiles of respondents and their business, the interviews addressed respondents' views regarding the impact and management approaches for coping with the pandemic crisis, asking: (a) What impact is COVID-19 having on your business?; and (b) What approaches or measures might you soon implement to cope with the pandemic?

Interviews, lasting 40 to 90 minutes each, were undertaken online or via telephone. Data collection coincided with the COVID-lockdown phase in Portugal, being carried out from March 16th to May 29th, 2020.

\footnotetext{
${ }^{3}$ This paper is a partial result of the three-year research project financed by the Fundação para a Ciência e Tecnologia (co-financed by COMPETE 2020 and FEDER), «TWINE - Cocreating sustainable Tourism \& WINe Experiences in rural areas», initiated in June 2018.
} 
Discourses were recorded, with respondents' authorization, and transcribed, resulting in c. 36,000 words uploaded for analysis on an NVivo database. This data was subsequently coded and subjected to content analysis using NVivo 12. For codification, previously identified key concepts from the literature and media debate were used as initial codes, with other codes emerging from the interpretation and codification process. Codes and sub-codes were constantly reviewed for consistency and recoded when necessary (Miles et al., 2014). To assure reliability, two authors coded all narratives together and, when necessary, a third author was consulted to overcome lack of agreement. The content analysis followed an interpretive perspective, with overlapping content observable and the same comment possibly being coded into more than one category.

NVivo provided the frequency of references of categories coded, 'encoding matrix queries' (relations between variables, for example, frequency of categories by gender), frequency of words (word cloud and word trees), and the correlation between categories (based on Pearson's coefficient). Finally, results were presented and discussed using examples of narratives extracted from the analysed comments, always protecting the respondent's identity.

\section{RESULTS}

\section{Interviewees' Profiles}

To assess the numerous perspectives across diverse types of tourism businesses, a range of agents of supply were interviewed (see Table 1): 29 wine producers offering traditional wine tasting, selling and winery tours; six accommodation owners; four restaurant managers, five tour operators/ agents, and three companies with two or more of some of these business types. In total, 47 interviews were carried out, 24 on the Dão wine route and 23 on the Bairrada wine route. Respondents mainly were aged over 40 and had completed higher education. On the Dão route women predominated; on the Bairrada, men predominated.

\section{Word cloud}

A word cloud reveals words most often used in a text, the size of each word indicating its importance. The word cloud shown in Figure 1 illustrates the most frequent words used in the narratives of wine tourism suppliers. These words are, in decreasing order of importance: act (fazer) (1.2\% of total references), wine $(0.7 \%)$, restaurant(s) $(0.7 \%)$, market $(0.5 \%)$, client $(0.5 \%)$, 
moment $(0.5 \%)$, price $(0.3 \%)$, selling $(0.3 \%)$, company $(0.3 \%)$, online $(0.3 \%)$, problem $(0.3 \%)$, time $(0.3 \%)$, and impact $(0.2 \%)$.

These results show that suppliers now live in a period that urges timely action to respond to the pandemic's impacts. Wines are amongst the main products of these regions, but their sales are highly dependent on the activity of restaurants, often tourist related. There is a concern to reactivate the markets, with price and sales strategies to attract customers, increasingly adopting online strategies to solve problems and counter the pandemic's impacts, in part switching from wine tourism to wine selling.

Table 1. Sample Characterization

\begin{tabular}{|c|c|c|c|}
\hline & Bairrada Wine Route & Dão Wine Route & Total \\
\hline \multicolumn{4}{|l|}{ Type of business } \\
\hline Wine producer & 15 & 14 & 29 \\
\hline Accommodation & 2 & 4 & 6 \\
\hline Restaurant & 2 & 2 & 4 \\
\hline Tour operators/ agencies & 2 & 3 & 5 \\
\hline $\begin{array}{c}\text { Companies with two or } \\
\text { more business types }\end{array}$ & 2 & 1 & 3 \\
\hline \multicolumn{4}{|l|}{ Gender } \\
\hline Male & 16 & 7 & 23 \\
\hline Female & 7 & 17 & 24 \\
\hline \multicolumn{4}{|l|}{ Age } \\
\hline below 40 & 4 & 6 & 10 \\
\hline 40 years or above & 19 & 18 & 37 \\
\hline \multicolumn{4}{|l|}{ Higher education } \\
\hline Yes & 13 & 19 & 32 \\
\hline No & 2 & 1 & 3 \\
\hline
\end{tabular}

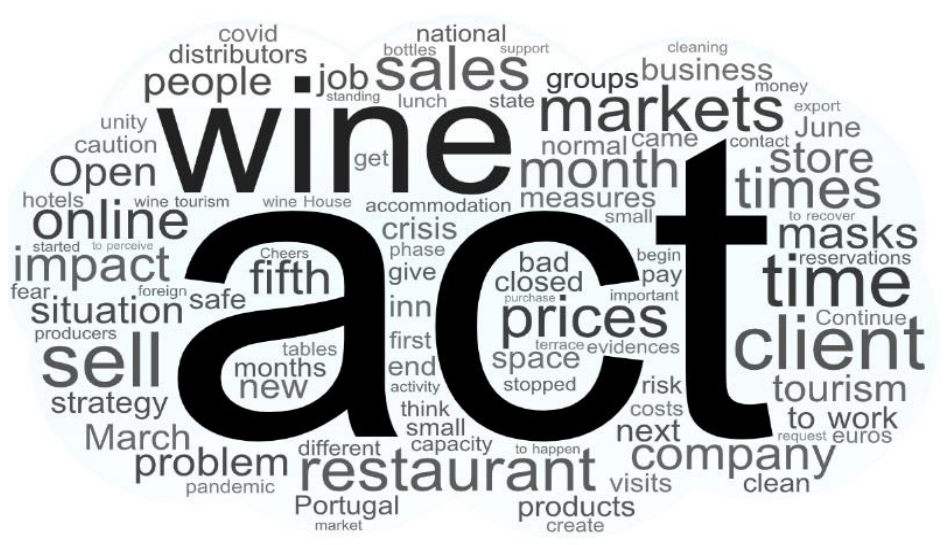

Figure 1. Word cloud 


\section{Impacts of COVID-19 on Wine Tourism}

Views on the impacts of COVID-19 are presented in Table 2. They refer to impacts on a) agents' internal operations, b) their markets/ customers, c) the entire value chain/ system and d) managers'/owners' personal beliefs.

Table 2. Perceived impacts of the COVID-19 pandemic - Category tree and respective absolute frequencies ( $n=47$ interviewees)

\begin{tabular}{|c|c|c|c|}
\hline Category & $\begin{array}{l}\text { Description: } \\
\text { SUPPLIERS COMMENT }\end{array}$ & $\begin{array}{l}\text { Number of } \\
\text { interviews }\end{array}$ & $\begin{array}{l}\text { Number of } \\
\text { references }\end{array}$ \\
\hline \multicolumn{4}{|c|}{ IMPACTS ON AGENTS' INTERNAL OPERATIONS: } \\
\hline $\begin{array}{l}\text { Increased responsibilities/work } \\
\text { load }\end{array}$ & COVID-19 added responsibilities/tasks & 4 & 6 \\
\hline Lack of storage capacity & lack of space to store new harvested wine & 7 & 8 \\
\hline Financial effects & TOTAL & 47 & 96 \\
\hline Financial losses & financial losses due to COVID-19 & 46 & 85 \\
\hline Unexpected spend & unexpected expenses in dealing with COVID-19 & 6 & 11 \\
\hline \multicolumn{4}{|c|}{ IMPACTS ON CONSUMERS / MARKETS: } \\
\hline Incompatibility & $\begin{array}{l}\text { inconsistency between } \\
\text { the product (wine), its social nature and COVID-19 } \\
\text { constraints }\end{array}$ & 2 & 3 \\
\hline Disturbed experience & compliance with new rules disturbs customer experience & 3 & 3 \\
\hline New demand requirements & new demands of clients (actual; anticipated) & 4 & 4 \\
\hline \multicolumn{4}{|c|}{ IMPACTS ON THE SYSTEM / DESTINATION/VALUE CHAIN: } \\
\hline Systemic effect & interaction between consequences of COVID-19. & 31 & 57 \\
\hline \multicolumn{4}{|c|}{ IMPACTS ON MANAGERS' / OWNERS' PERSONAL BELIEFS: } \\
\hline Emotional tone & Emotional tone in suppliers' narratives. & 47 & 174 \\
\hline Negative & TOTAL & 47 & 117 \\
\hline Discontent/contestation & $\begin{array}{l}\text { Suppliers: express discontent, distrust or } \\
\text { incomprehension of government and public institutions }\end{array}$ & 6 & 11 \\
\hline Disappointment & $\begin{array}{l}\ldots \text { describes a scenario that removes high expectations } \\
\text { for the current year }\end{array}$ & 13 & 16 \\
\hline Uncertainty & $\ldots$ are doubtful & 18 & 33 \\
\hline Fear & $\ldots$ are afraid / refer to the fear of others & 13 & 21 \\
\hline Anxiety & $\ldots$ are stressed/ refer to the stress of others & 7 & 9 \\
\hline Pessimism & $\ldots$ are pessimistic & 12 & 20 \\
\hline Sadness & ... express sadness & 2 & 2 \\
\hline Anger/revolt & ... express anger / revolt & 4 & 5 \\
\hline Positive & TOTAL & 35 & 57 \\
\hline Acceptance & $\begin{array}{l}\text { Suppliers: are resigned to or accept the new } \\
\text { circumstances }\end{array}$ & 8 & 11 \\
\hline Optimism, hope & $\ldots$ are optimistic or confident & 16 & 27 \\
\hline Resilience & ... show the ability to face adversity & 11 & 19 \\
\hline
\end{tabular}

With regards to the impact of COVID-19, suppliers refer, above all, to direct impacts on their own businesses, particularly to severe financial losses ( $n=85)$ : "We had brutal drops in our income, in our sales abroad, all those existing were cancelled. It had a tremendously negative impact". (Wine producer, Bairrada)

Six supply agents also pointed to unexpected expenses $(n=11)$ (e.g., purchase of new protective equipment such as masks and disinfectant). One accommodation manager remarked: "Those who live on it are trying to take action, but those who don't live on it are wondering if the investments they have to 
make and the opening costs will pay off, which is our case. Our costs are too high..." (Accommodation owner, Bairrada)

Associated with additional costs are increased responsibilities and new tasks $(n=6)$ due to the pandemic. Other relevant impacts on businesses referred to lack of wine storage capacity, $(n=8)$ : "I have a cellar full of wine and I have nowhere to put the next harvest. This is happening with more than $50 \%$ of producers". (Wine producer, Bairrada)

Another massively recognized impact is the pandemic's systemic effect $(n=57)$, i.e. the highlighted interdependence of adverse crisis-linked effects amongst different agents of supply and at regional, national and even global scale: "The national market is largely paralyzed because we work through regional distributors. We have someone who distributes [our wines] in the Algarve, in Lisbon and, as you know, these distributors have the restaurants and some stores as main customers and all these activities have suffered tremendously from this situation and continue to suffer because naturally the here predominant customers being international tourists who are not going to a country with very alarming numbers". (Wine producer, Bairrada)

Only a few remarked-on impacts on consumers and markets. For example, some suppliers consider that COVID-19 has created incompatibility between their main product (wine), what it represents and the general state of mind of their clients $(n=3):$ " $(\ldots)$ people are also desolated; they do not have a great appetite for drinking and end up drinking what they have in the cellar. Not going to the restaurant, not going to the street ... There are no celebrations at all, it's sad ... our business represents joy, celebrating ..." (Wine producer, Bairrada).

Tourists were felt to be disturbed by the rules imposed to deal with COVID-19 $(n=3)$, as described by a restaurant owner: "the tables are not set, we have to set them on the spot, which is horrible, it is very impersonal and it gets hideous. The serviettes have to be put on the spot, the cutlery, the glasses, that is, the tables are on display are visible and it is very ugly ..." (Restaurant, Dão). Some also reported visitor fears about getting a guaranteed safe experience, e.g.: "Portuguese people started asking a lot of questions and the question they asked most was about the pool, whether the pool was in common use or whether it was private, which in this case it is not, it is common to [several] houses..." (Accommodation owner, Dão)

All suppliers expressed negative emotional reactions to the pandemic: sadness, revolt, discontentment, anxiety, disillusion, pessimism, fear and uncertainty - the last three being the most evident with 20, 21 and 
33 references, respectively. An interviewee from the Dão wine route said: "This is a year to forget. I put that in my head to hurt less. I got it in my head that we would only work for next year, losing the summer. I think we lost everything". (Wine producer, Dão)

The positive emotional tone is represented by acceptance, resilience and optimism/ hope, the latter being the most evident ( $n=27)$, as visible, for example, in the answer of an interviewee: "But let's hope that this is going to get better, everyone says it will pass and it will get better and I am an optimist by nature". (Wine producer, Bairrada).

\section{Management Approaches Adopted by Wine Tourism-Related Businesses}

Data reveal the strategies and approaches adopted by wine tourism-related businesses, that may be classified according to the Mitroff model's different stages (Pearson \& Mitroff, 1993, see section 2.2.), namely 1) Prevention, 2) Containment (damage limitation), 3) Learning and redesign and 4) Business recovery. It is noteworthy that these stages often overlap; for example, a learning and redesign measure can be simultaneously a containment effort, while planning activities are also future-orientated, imply analytical learning and present the basis for the redesign. Management strategies in the containment stage are the most prominent, as documented in interviewees' discourses in Table 3.

Table 3. Approaches adopted by wine tourism-related businesses - Category tree and respective absolute frequencies ( $n=47$ interviews)

\begin{tabular}{|c|c|c|c|}
\hline Category & $\begin{array}{l}\text { Description } \\
\text { SUPPLIERS }\end{array}$ & $\begin{array}{l}\text { Number of } \\
\text { interviews }\end{array}$ & $\begin{array}{l}\text { Number of } \\
\text { references }\end{array}$ \\
\hline PREVENTION & $\begin{array}{l}\text {... note that they had prepared in some way for situations of } \\
\text { difficulty or crisis }\end{array}$ & 4 & 5 \\
\hline $\begin{array}{l}\text { CONTAINMENT } \\
\text { (damage limitation) }\end{array}$ & Actions were taken to limit pandemic crisis spread & 47 & 311 \\
\hline Passivity & & 14 & 17 \\
\hline Devaluing the problem & Suppliers dismiss the problem. & 1 & 2 \\
\hline Waiting for it to pass & $\begin{array}{l}\text {... have a passive attitude towards the problem, expecting an } \\
\text { external change that might solve their business problems }\end{array}$ & 7 & 9 \\
\hline $\begin{array}{l}\text { External control locus/Visitor } \\
\text { behaviour }\end{array}$ & $\begin{array}{l}\ldots \text { value the behaviour of customers for the evolution of the } \\
\text { situation }\end{array}$ & 6 & 6 \\
\hline Planning & $\begin{array}{l}\text { Set of strategies enhancing the analytical capacity of suppliers } \\
\text { about the COVID-19 context }\end{array}$ & 31 & 43 \\
\hline Analyse the situation & $\begin{array}{l}\text { Suppliers think about the COVID-19 situation, try to understand, } \\
\text { look for expertise (e.g., training), place comprehensive } \\
\text { hypotheses }\end{array}$ & 14 & 19 \\
\hline $\begin{array}{l}\text { Privileging the sale of wine over } \\
\text { wine tourism }\end{array}$ & ...favour the sale of wine, placing wine tourism second & 4 & 5 \\
\hline $\begin{array}{l}\text { Cancellation of planned } \\
\text { investments }\end{array}$ & Suppliers cancel planned investments & 2 & 3 \\
\hline $\begin{array}{l}\text { Recognition of the need for } \\
\text { change }\end{array}$ & $\begin{array}{l}\text {... recognizing the need for change to adapt to new realities, } \\
\text { even if doing nothing concrete yet }\end{array}$ & 8 & 13 \\
\hline Follow other models & $\begin{array}{l}\text {... observe what colleagues are doing, seek to adopt/ import } \\
\text { existing models to face the pandemic }\end{array}$ & 3 & 3 \\
\hline
\end{tabular}




\begin{tabular}{|c|c|c|c|}
\hline Human resources & Impact described at HR level & 13 & 16 \\
\hline Dismissals & Suppliers dismiss employees not needed & 2 & 3 \\
\hline Lay-off & or lay-off staff & 2 & 2 \\
\hline Homeworking & Adopt teleworking when possible & 3 & 3 \\
\hline Training & Investment in training. & 6 & 8 \\
\hline Finance & Strategies referred to financial aspects & 3 & 4 \\
\hline $\begin{array}{l}\text { Financial support (subsidies and } \\
\text { tax reductions) }\end{array}$ & Activation/use of specific financial or social state support & 3 & 4 \\
\hline Operational strategies & Diverse operational measures including & 95 & 140 \\
\hline Face-to-face work activity & Regulate face-to-face components of the business & 28 & 34 \\
\hline Acquisition of new equipment & $\begin{array}{l}\text { Investment in further protection (e.g., masks) and signage } \\
\text { equipment }\end{array}$ & 5 & 9 \\
\hline Social distance & $\begin{array}{l}\text { Measures to improve social distancing (e.g., reducing the } \\
\text { capacity of spaces) }\end{array}$ & 12 & 25 \\
\hline Hygiene measures & Adoption of sanitary measures & 18 & 31 \\
\hline $\begin{array}{l}\text { Protection, involvement with the } \\
\text { community/ solidarity actions }\end{array}$ & $\begin{array}{l}\text { Involvement in solidarity actions to combat COVID-19 or valuing } \\
\text { those "on the front line" }\end{array}$ & 2 & 5 \\
\hline Signage & $\begin{array}{l}\text { Investment in signage reminding visitors of safety norms/ } \\
\text { behaviours }\end{array}$ & 2 & 2 \\
\hline Temporary closure & Temporarily close business activity (optional or mandatory) & 22 & 27 \\
\hline Keeping the business open & Maintain face-to-face activity during lockdown & 5 & 6 \\
\hline Work schedule change & Adapt work schedules to the COVID-19 context & 1 & 1 \\
\hline Marketing & & 72 & 96 \\
\hline Markets & Type of privileged marketing during pandemic & 14 & 21 \\
\hline International & & 3 & 4 \\
\hline National/Local & & 11 & 17 \\
\hline Experience design & & 31 & 39 \\
\hline $\begin{array}{l}\text { Strengthen the relationship } \\
\text { or face-to-face contact }\end{array}$ & Valuing personal contact with consumers or distributors. & 2 & 3 \\
\hline Authentic experiences & Promoting authentic, unique experiences & 2 & 2 \\
\hline Outdoors/ Nature & Favouring outdoor spaces for activities & 9 & 11 \\
\hline Smaller groups & Offering personalized service & 4 & 4 \\
\hline $\begin{array}{l}\text { Transmitting confidence to } \\
\text { visitors }\end{array}$ & $\begin{array}{l}\text { Promoting a feeling of security (e.g., acquiring the official } \\
\text { certificate Clean \& Safe) }\end{array}$ & 14 & 19 \\
\hline \multicolumn{4}{|l|}{ Communication and Distribution } \\
\hline & & 21 & 28 \\
\hline Digital communication & Invest in the online presence (e.g., social networks) & 7 & 8 \\
\hline Large commercial areas & ...seeking to sell products in large commercial areas & 2 & 3 \\
\hline Search for customers & ...try to recruit "door to door" customers & 1 & 1 \\
\hline Sales promotions & $\begin{array}{l}\text {...adjust prices to target market identified during the pandemic } \\
\text { or adapt offer }\end{array}$ & 8 & 13 \\
\hline $\begin{array}{l}\text { Take away and delivery } \\
\text { services }\end{array}$ & ...develop or favour takeaway or delivery services & 3 & 3 \\
\hline online market & ...using the online market as an alternative to face-to-face sales & 12 & 18 \\
\hline $\begin{array}{l}\text { Evaluation of online market } \\
\text { as insufficient }\end{array}$ & $\begin{array}{l}\ldots \text { assess the online market as insufficient to cover financial } \\
\text { losses due to COVID-19 }\end{array}$ & 8 & 11 \\
\hline Prices & Price impact & 6 & 8 \\
\hline Increase prices & Need to increase prices & 2 & 2 \\
\hline Lower prices & Need to lower prices & 4 & 6 \\
\hline BUSINESS RECOVERY & Suppliers show signs of business recovery & 8 & 10 \\
\hline LEARNING AND REDESIGN & $\begin{array}{l}\text {... reveal learning (better prepared for future crises) and } \\
\text { proactivity (opportunity to reinvent the business) }\end{array}$ & 16 & 24 \\
\hline
\end{tabular}

\section{Prevention $(n=5)$}

Few interviewees mentioned that they had prepared for a possible crisis by saving for unforeseen difficulties: a wine producer said: "I am spending money from a secured account that I had previously from last year ... and now I am using it". (Wine producer, Bairrada). 


\section{Containment / lockdown $(n=311)$}

The aspects mentioned here show interviewees' concern with the most significant impacts of the pandemic. Financial problems resulting from the compulsory shutdown, decrease in demand, and new operational requirements were preeminent issues. The following strategies were the most evident:

Because the pandemic was totally unexpected, it requires careful and continuous monitoring, analysis, planning and sometimes radical changes $(n=43)$; in the words of this interviewee: "We are rethinking the whole commercial strategy". (Wine producer, Dão)

Many supply agents $(n=34)$ adopted strategies to regulate the faceto-face component of their business. Most businesses temporarily closed, at least during the lockdown $(n=27)$, e.g.: "In wine tourism, it [business] stopped completely, even by our decision, even though we had the opportunity to reopen doors little by little, we decided for the sake of conscience and protection of our team and our work not to open the doors". (Wine producer, Dão)

Hygiene related measures are a strong concern for supply agents ( $n$ $=31$ ), as well as social distancing measures $(n=25)$, introduced into the tourist experience design, illustrated below:

"Access to the store is only allowed to two people... wearing masks, with hand hygiene, with the rules that everyone is adopting, access to the cellar to make the visit, a maximum of six people. I work in terms of corridors, and I will be able to separate three people on each side with a distance of two metres between them so without any kind of problem. For now, we will have to work like this, and we cannot work with crowds...". (Wine producer, Dão)

The transmission of trust to customers also emerged as an important strategy $(n=12)$. An example of this follows: "I will try to pass on some confidence so that people can visit this small space because small [scale] environments can be more controlled". (Wine producer, Bairrada)

Some suppliers are also trying to develop activities outdoors $(n=11)$, for example: "We are going to be working harder this year than other years on the outdoor part, the terrace part". (Wine producer, Dão). Some strategies concerning experience design stress the promotion of authenticity, prioritizing smaller groups, the role of new equipment and staff training.

Many wine producers are trying to take advantage of online sales ( $n$ $=18$ ), despite recognizing them as insufficient to cover their financial losses 
( $n=11)$, e.g.: "On the one hand, [we try] to diversify the product supply channels. Social networks, online sales, everyone says they sell, but it is very residual because direct contact is very important". (Wine producer, Bairrada)

Some agents are also trying to diversify their communication and sales channels and targets $(n=28)$, using promotions or adapted packages $(n=13)$ and focusing on national markets $(n=17)$, illustrated by: "What I' $m$ doing is, since I worked a lot with the foreign market and I can't do it, I created new packages, shorter for the weekend, 4 or 5 days, and aimed at a national target because there is no other option". (Tour operator, Bairrada)

Notwithstanding the above, some suppliers present a posture of passivity $(n=17)$, essentially in three different ways:

- devaluation of the problem $(n=2)$

"Yesterday I saw an interview with the main virologist in Portugal that devalued COVID a lot. It was an opinion I shared" (Wine producer, Bairrada)

- "waiting for it to pass" $(n=9)$

"Right now, we're just waiting for the market to reactivate itself. Because, the solutions to find new customers ... other countries are going through the same thing as us and, therefore, it is not there and therefore, the strategy is to wait for it to reactivate." (Wine producer, Bairrada)

- external locus of control (visitor accountability) $(n=6)$

"Going to the restaurant is the situation of being seated next to other people who may not be sensitive to the disease, may not be responsible and this can create discomfort for the customer ... I don't want to go to the restaurant because I don't feel good because people are not careful about anything. What is at stake here is the extent to which people's behaviour in restaurants will allow confidence so that we can continue to go to the restaurant". (Restaurant, Bairrada)

Although mentioned only by a few interviewees, it is essential to list other aspects that required the strategic attention of the agents (Table 3): human resources management, redefinition of prices, activation of financial support (subsidies and tax reductions), involvement with the community/solidarity actions, strengthening relationships with clients or distributors. 


\section{Learning and redesign $(n=24)$}

Many supply agents were proactive, creating new products suitable for the pandemic period, thus: "We will adjust our programmes and our costs more to the national market, in a Road Trip, in which people do not leave the car and visit the places. There, it will be more in that scope". (Tour operator, Bairrada)

Learning and redesign emerges, see above, as a form of crisis damage containment.

\section{Business recovery $(n=9)$}

Some supply agents mentioned that business was recovering after a few months of enormous difficulties, as in this case: "I honestly thought it was worse. In the first two months it was challenging, but at the moment I cannot be a hypocrite, it is going well". (Wine producer, Bairrada)

\section{Association Between Impacts Perceived, Stage of The Crisis, Region and Sample Profile}

As expected, the average number of references (sum of references $\div$ number of interviews) related to the impact of the pandemic was higher during the lockdown than afterwards $(M=3.22$ vs $M=2.21)$. The same trend is observable in the higher negative emotional tone in the confinement phase compared to post-confinement ( $M=2.00$ vs $M=0.43$ ).

Interestingly, although there was a more minor difference between the two phases, in the first phase, the average number of positive references remains higher than later ( $M=0.75$ vs $M=0.57$ ), perhaps due to higher uncertainty about the pandemic at first, mixed with the expectation of the crisis passing quickly.

As for the stages of the Mitroff model, reports of business recovery are present mainly after lockdown ( $M=0.03$ vs $M=0.29)$, despite lockdown approaches dominating both periods. Congruent with this idea of recovery after lockdown, passivity is present mainly in narratives collected during lockdown $(M=0.37$ vs $M=0.07)$.

The two routes differ mainly concerning the impact of COVID-19, with more negative references $(M=3.22$ vs $M=2.58)$, and negative emotional tone slightly more evident in Bairrada compared to Dão $(M=1.87$ vs $M=1.30)$. But on the Dão route more references to containment measures are reported $(M=4.45$ vs $M=3.87)$, suggesting more proactivity there regarding the adoption of strategies to minimize negative impacts. 
When comparing wine tourism businesses with those without (only with wine production), the most evident difference related to the emotional tone, markedly more negative in businesses with wine tourism $(M=1.82 \mathrm{vs}$ $M=0.50$ ), which may be due to the higher pandemic risks in tourism activities associated with their social component.

Older respondents (41 years old and over) tend to report, on average, more impacts from COVID-19 $(M=3.06$ vs $M=2.40)$ and a more expressive emotional tone, both with a negative ( $M=1.77$ vs $M=0.68)$ and a positive valence ( $M=0.65$ vs $M=0.10$ ). Interestingly, men interviewed also referred, on average, to a greater number of impacts $(M=3.30$ vs $M=2.64)$ and presented a more negative emotional tone $(M=2.04$ vs $M=1.14)$, than women.

\section{Associations Between Types of Impacts, Emotions and Strategies Adopted}

Pearson's correlation coefficient ( $r$ ) was calculated to analyse the relationship between coded categories, considering only strong correlations, with a cut-off value of 0.7 (Pestana \& Gageiro, 2008).

Firstly, we found that financial losses appear strongly and positively correlated with the systemic effect $(r=0.98)$, illustrating the role of interdependence between agents of supply, in particular between wine producers and restaurants. In addition, financial losses are also positively and strongly associated with both negative emotional tone - pessimism $(r=$ $.93)$, uncertainty $(r=.92)$ and fear $(r=.91)$ - but also with positive emotional tone - optimism/hope $(r=.93)$.

This paradoxical emotionality extends to strategies adopted. For example, hygiene measures and social distancing appear simultaneously associated with hope and uncertainty $(.88<r<.92)$. The same is true regarding sales promotions, both positively correlated with hope $(r=.90)$ and uncertainty $(r=.90)$. Also, the category 'analyse the situation' appears associated with uncertainty $(r=.91)$, pessimism $(r=.88)$ and fear $(r=.87)$ but also with hope $(r=.87)$. Similarly, the containment strategy 'favour the national market' is associated with both hope $(r=.89)$ and uncertainty $(r=$ .87). Even 'learning and redesign', which appears mainly related to hope $(r$ $=.90)$ and resilience $(r=.89)$, is also positively associated with pessimism $(r$ $=.88$ ). Therefore, this pandemic context seems to be bounded by doubts, paradoxical emotions and uncertainties about COVID-19 coping strategies, which makes sense in this period of unknown/ uncontrollable futures. 
Secondly, considering the stages of the Mitroff model, it is important to highlight that containment (damage limitation) - social distance, hygiene measures, sales promotion - and business recovery are positively and strongly associated $(0.7<r<0.9)$. The latter is also positively and strongly associated with the learning and redesign stage $(r=0.74)$.

Importantly, passivity appears positively and strongly associated with pessimism $(r=.86)$, financial losses $(r=.85)$, fear $(r=.84)$, discontent with/contestation of the macrosystem $(r=.83)$ and disillusionment $(r=.78)$.

Semone (2007) wrote "there will be another crisis for the tourism industry, and when it rears its ugly head we must respond in a quick, agile and professional fashion" (p. xvii). These words are very relevant, and, as Scaglione (2007, p.13) puts it: "How bad will the effects be, and how long will they last?".

\section{DISCUSSION AND CONCLUSIONS}

According to Hall (2010), many of the crisis events now affecting tourism have been distressing societies for millennia. What has changed is the dramatic growth in the scale of travel in our hypermobile society. This increases the potential impacts of disasters and crises affecting it (Folinas \& Metaxas, 2020; Scott et al., 2012). Tourism had experienced crises before COVID-19, related to contagious diseases (e.g. the 2003 SARS virus), terrorist attacks (e.g. 11-09-2002) or the 2008-2018 economic crisis. In all previous cases, international travel continued growing, despite occasional decreases or stagnation. The tourism system has proven to be resilient to external shocks (Gössling et al., 2021). However, the systemic impact of COVID-19, which affects all human activities, particularly those driven by social gathering and mobility, is disastrous for the tourism sector (Folinas \& Metaxas, 2020). Many tourism-related industries, such as airlines, are deeply affected (IATA, 2020). Several airlines are close to collapse. Many of Portugal's tourists - including wine tourists - come by air. Air travel seems likely to continue to be reduced throughout 2021.

This research shows the wine tourism sector of rural tourism to be impacted by COVID-19 in many and quite complex ways. It provides several theoretical and practical contributions. Overall, businesses feel the need to act urgently but appear very unsure about how to act. They appear to have had little advice about how best to change their operational practices, nor have they developed new marketing policies to help overcome the fears of potential tourists. 
Negative emotions were strong and, notably, correlated to passivity and contradictory feelings. This situation, associated with a highly uncertain future context, calls for the need to strengthen individual and collective resilience (Cartier \& Taylor, 2020; Dahles \& Susilowati, 2015; McManus et al., 2008). Recovery (the ability to return to the original state) and transformation (the ability to create new development opportunities for a system) are two possible paths to resilience (Tsao \& Ni, 2016) and, in the case of this pandemic, necessary changes are eminently of a structural nature. These clearly imply the transformation of the systems involved rather than the recovery of the original balance, which is why it is essential that the systems find new equilibrium states for their survival, building a new normality. Social change and social resilience are needed in this context and can contribute to new structures that help overcome barriers to economic development and social shortcomings (Diedrich \& Aswani, 2016), which in turn influence and are influenced by tourism itself as an important driver of social transformation (Füller \& Michell, 2014). In fact, an event such as a pandemic requires social depth and the capacity of societies to rise up in the face of the stress generated, thus enabling human development and social futures (Cheer \& Lew, 2018).

Businesses seem very aware of the systemic impact of the pandemic on wine tourism, amplifying the consequent economic and social crisis. These systemic impacts that easily disseminate from company to company, from one place to another and even from one sector to another, reflect the nature of tourism as an open system and call for coordination and concerted strategies for 'post-disaster reconstruction' (Nian et al., 2019). They also echo the call for second-generation rural tourism, with its decentralised sustainable destination management, to collectively cope with such situations (Lane \& Kastenholz, 2015).

Second, the study identifies low levels of preparedness for the crisis, and a variety of ad-hoc strategies adopted by wine tourism suppliers. The approaches most adopted are hygiene and social distancing measures, temporary business closures, careful analysis and planning of operations, and using online promotion and distribution more intensely. Findings partially corroborate the results of previous research on strategies adopted in health crises in tourism (e.g. Henderson, 2004; Kim et al., 2005). Specific responses developed by wine tourism agents, focus on online wine sales versus wine tourism or favouring the development of activities in outdoor sites. The latter is particularly appropriate when considering not only the lower risk of contagion outdoors, but also the particular landscape appeal of wine regions and wineries. This, together with the search for authentic, 
slow and personalized, non-mass tourist experiences in rural and natural settings (Oh et al., 2016; Quadri-Felitti \& Fiore, 2012), should be understood as a valuable new experience proposal, a redesign strategy to be maintained in the post-COVID reality. Results also suggest the need for investing more in social measures as an opportunity to develop community/solidarity actions, eventually enhancing the building of community resilience and social capital at the destination level (Cartier \& Taylor, 2020). As a consequence, crises may not only bring challenges and oblige people to drastically change plans and operations (Laws et al., 2007), but they may also bring opportunities (e.g., the quality of the health response; the acceleration of the digitalization of tourism operations) to redesign businesses, creating more attractive, innovative and successful wine tourism products and destinations (Almeida \& Silva, 2020; Nian et al., 2019).

Third, the results suggest that the perceived impacts of COVID-19 on wine tourism and consequent strategies adopted depend not only on the crisis stage, but also on the profile of the respondent, such as gender and age, with men and older respondents perceiving relatively more impacts and reporting more emotional reactions (men particularly negative ones). The regional context is shown to affect perceptions of the crisis and strategies developed, with agents from the Dão route being slightly more optimistic about the impacts of the crisis and also presenting more strategies to overcome it. This may be linked to the route's poorer tourism development, with impacts not felt as much as in Bairrada. Also, this interior region's agents may expect more tourists eventually seeking rural, less congested areas in the post-containment period.

Fourthly, there are lessons for the concept of sustainable tourism as well as rural tourism. Early results from work in progress in Italy's South Tyrol show that the environment and its conservation dominates the sustainable tourism thinking of most tourists ${ }^{4}$. The concept of the "triple bottom line" (environment, society/ culture, and economy) receives little attention, with the local economy often totally taken for granted, an issue also noted by Moyle et al. (2020). More attention needs to be paid to the local economy, and to drawing up crisis management plans as an integral part of sustainable tourism strategy planning for both COVID and other crises (see Bausch et al., 2021).

Additionally, this research almost accidentally provides insights into the potential consequences of a concept that has fascinated academic

\footnotetext{
${ }^{4}$ See https://sustainabletourism.eurac.edu/publications/\#report2020
} 
commentators on sustainable tourism for many years. De-growth has long been discussed as a way to achieve sustainability (Hall, 2009; HigginsDesbiolles et al., 2019). De-growth continues to haunt the thoughts of the industry who fear its financial and political consequences. COVID-19 has created unexpected and sudden de-growth situations. The findings in this paper reveal both the practical and deep psychological impacts on all who are working to manage and deliver tourism in de-growth situations.

Finally, what do results mean for rural tourism? The ongoing rise of rural tourism since the 1970s as a low cost and proven way of achieving rural regeneration, with strong environmental conservation possibilities (OECD, 1994; Lane, 2009), is now questioned. Specifically, many wine tourism businesses talked about abandoning tourism and pluriactivity, relying solely on wine production and selling through (online) agents, thus withdrawing from the diversification of agricultural and other rural businesses into tourism while retaining their original activity (Stanford \& Guiver, 2016; Sharpley \& Pearce, 2007). Wine and rural tourism have suffered the severe negative financial impacts of crises in tourism as have other forms of tourism (Page et al., 2012; Zeng et al., 2005). The research presented here also shows the tremendous negative psychological effects of COVID-19 on these tourism businesses, impacts that are conditioning their future plans, strategies and actions.

Rural tourism's inherent weaknesses have been exposed: its many independent businesses, its lack of partnership working, and its lack of skilled governance have rendered its businesses open to fear, uncertainty and lack of leadership about the future of tourism as a revenue earner. At this time, local and regional marketing is especially essential to stress the relative safety of rural tourism. However, many of the local and national rural tourism management and marketing groups have been abandoned in favour of using low cost internationally managed internet-based booking companies such as booking.com (Gössling \& Lane, 2015). Numerous research respondents felt alone and disillusioned by the lack of local and national guidance and assistance.

This paper thus offers some important practical and theoretical contributions. It highlights the need for strategies that are adopted by a more closely linked and innovative set of players, possibly leading to the development of more appealing and sustainable wine destination experiences. These approaches include personalization, small scale enterprise development, ascribing and interpreting value to nature and landscape, community involvement and social responsibility, making the 
entire destination system more resilient for future crises. One growing area is that of using a personal smartphone to access guided interpretive walks available on the web (go to: https://soundcloud.com/tom_lane/tom-lanestream-of-consciousness/s-2NthNpv1gCe, to experience an urban example). Such systems are COVID proof, give access to music, song and poetry, and have proven to be popular and fashionable where introduced. They exemplify the advantages of businesses working in partnership to spread innovation costs and benefits.

However, the study also reveals that some interviewees still have a passive attitude towards the crisis and are mainly concerned with shortterm measures and financial survival. Although understandable, a more ambitious approach implying learning and improved future action would probably require the acquisition of skills by both single actors as well as destination systems. Social capital creation to cope with present pandemic as well as future crises in a more appropriate way, i.e. combining both competences of risk and crisis management (McManus et al., 2008) could have significant advantages.

This paper has some limitations. It only analyses the effects of the COVID-19 pandemic in two wine tourism regions in Portugal; an extension of the study to other locations would permit validation of some results or understanding of additional moderating, context-dependent variables. Longitudinal research, analysing the impacts and strategies developed, according to the evolution of this ongoing crisis, is also needed. Research regarding the crisis' effects on other stakeholders, specifically on travellers, to adapt supply more appropriately, and on the local communities, cocreating wine tourism experiences would also be interesting.

Rural tourism businesses act very independently, as described long ago in Lane (1994). Lane and Kastenholz (2015) envisaged a more secure future for new generation rural tourism based on sustainable local partnerships, creating decentralized rural destinations, a concept well suited to wine routes. But partnerships are complex and time-consuming to create and operate, and need incentives, professional skills and advice (Selin, 1999). Continuous research on practical network cooperation and governance is, therefore, still needed to help create thriving and resilient rural wine tourism destinations. Ideas for doing that could be taken from healthcare reactions to COVID 19, which seek to show scientific and well thought out approaches, and to combat the feeling of helplessness affecting many small tourism businesses. A national - or regional - advisory group could be created, bringing together informed academic researchers, aware 
of local and international research on the subject, tourism consultants, used to working with tourism businesses, and public sector experts and politicians, together with communicating ways forward via the media, the web and zoom meetings to those many businesses that are pessimistic and fear collapse.

\section{ACKNOWLEDGMENT}

This work was developed in the scope of the research project TWINE PTDC/GES-GCE/32259/2017 - POCI-01-0145-FEDER-032259, funded by the ERDF through the COMPETE 2020 - Operational Programme Competitiveness and Internationalization (POCI), and national funds (OPTDC/GES-GCE/32259/2017 -E), through FCT/MCTES.

\section{REFERENCES}

Almeida, F., \& Silva, O. (2020). The impact of COVID-19 on tourism sustainability: Evidence from Portugal. Advances in Hospitality and Tourism Research, 8(2), 440-446. doi: 10.30519/ahtr.775340

Blake, A., \& Sinclair, M. T. (2003). Tourism crisis management: US response to September 11. Annals of Tourism Research, 30(4), 813-832.

Bruwer, J., Coode, M., Saliba, A., \& Herbst, F. (2013). Wine tourism experience effects of the tasting room on consumer brand loyalty. Tourism Analysis, 18(4), 399-414.

Bruwer, J., \& Rueger-Muck, E. (2019). Wine tourism and hedonic experience: A motivationbased experiential view. Tourism and Hospitality Research, 19(4), 488-502.

Bausch, T., Schröder, V., Tauber, V., \& Lane, B. (2021). Sustainable tourism: The elephant in the room. Sustainability 2021, 13(15), 8376. doi.org/10.3390/su13158376

Carneiro, M. J., Lima, J., \& Silva, A. L. (2015). Landscape and the rural tourism experience: identifying key elements, addressing potential, and implications for the future. Journal of Sustainable Tourism, 23(8-9), 1217-1235.

Cartier, E. A., \& Taylor, L. L. (2020). Living in a wildfire: The relationship between crisis management and community resilience in a tourism-based destination. Tourism Management Perspectives, 34, 100635. doi: 10.1016/j.tmp.2020.100635.

Charters, S., \& Ali-Knight, J. (2002). Who is the wine tourist?. Tourism Management, 23(3), 311-319.

Cheer, M., \& Lew, A. (2018). Tourism, Resilience and Sustainability: Adapting to Social, Political and Economic Change. New York: Routledge.

Correia, A., Vaughan, R., Edwards, J., \& Silva, G. (2014). The potential for cooperation between wine and tourism businesses in the provision of tourism experiences: The case of the Douro valley of Portugal. Revista Portuguesa de Estudos Regionais, 36(1), 43-55.

Dahles, H., \& Susilowati, T. P. (2015). Business resilience in times of growth and crisis. Annals of Tourism Research, 51, 34-50.

Diedrich, A., \& Aswani, S. (2016). Exploring the potential impacts of tourism development on social and ecological change in the Solomon Islands. Ambio, 45, 808-818. doi:10.1007/s13280-016-0781-x 
Folinas, S., \& Metaxas, T. (2020). Tourism: The great patient of coronavirus COVID-2019. MPRA Paper 99666, University Library of Munich, Germany.

Füller, H., \& Michel, B. (2014). New dynamics of urban tourism in Berlin. International Journal of Urban Regional Research, 38, 1304-1318. doi: 10.1111/1468-2427.12124

Forbes. (2020). Coronavirus Layoffs: Boeing Lays Off 6,770 Workers Amid Pandemic. Retrieved June $\quad 01$ 2020, from https://www.forbes.com/sites/lisettevoytko/2020/05/27/coronavirus-layoffsboeing-lays-off-6770-workers-amid-pandemic/\#32c4f7cb45bd

Gössling, S., \& Lane, B. (2015). Rural tourism and the development of Internet-based accommodation booking platforms: a study in the advantages, dangers and implications of innovation. Journal of Sustainable Tourism, 23(8-9),1386-1403.

Gössling, S., Scott, D., \& Hall, C. M. (2021). Pandemics, tourism and global change: A rapid assessment of COVID-19. Journal of Sustainable Tourism, 29(1), 1-20.

Guedes, A., \& Joukes, V. (2015). Hotel ships on the Douro river and their relationship with the terroir. In M. Peris-Ortiz, M. Rama, \& C. Rueda-Armengot (Eds.), Wine and Tourism: A Strategic Segment for Sustainable Economic Development (pp. 87-105). Germany: Springer.

Hall, C. M. (2009). Degrowing tourism: Décroissance, sustainable consumption and steadystate tourism. Journal of Sustainable Tourism, 20(1), 46-61.

Hall, C. M. (2010). Crisis events in tourism: subjects of crisis in tourism. Current Issues in Tourism, 13(5), 401-417.

Hall, C. M., Longo, A. M., Mitchell, R., \& Johnson, G. (2000). Wine tourism in New Zealand. In C. M. Hall, L. Sharples, B. Cambourne, \& N. Macionis (Eds.), Wine Tourism Around the World: Development, Management and Markets (pp. 150-174). Oxford: Elsevier Science.

Henderson, J. C. (2004). Managing a health-related crisis: SARS in Singapore. Journal of Vacation Marketing, 10(1), 67-77.

Higgins-Desbiolles, F., Carnicelli, S., Krolikowski, C., Wijesinghe, G., \& Boluk, K. (2019). Degrowing tourism: rethinking tourism. Journal of Sustainable Tourism, 27(12), 1926-1944.

Holland, T., Smit, B., \& Jones, G. V. (2017). Toward a conceptual framework of terroir tourism: a case study of the Prince Edward County, Ontario Wine Region. Tourism Planning and Development, 11(3), 275-291.

IATA (2020). COVID-19: Updated Impact Assessment. Retrieved December 27, 2020, from https://www.iata.org/en/iata-repository/publications/economic-reports/thirdimpact-assessment/

Jamal, T., \& Budke, C. (2020). Tourism in a world with pandemics: Local-global responsibility and action. Journal of Tourism Futures, 6(2), 181-188.

Kastenholz, E. (2018). Tourism and specific localities - mountains, deserts and coasts. In C. Cooper, B. Gartner, N. Scott, \& S. Volo Sag (Eds.), Handbook of Tourism Management (pp. 493-515). London: Sage.

Kim, S. S., Chun, H., \& Lee, H. (2005). The effects of SARS on the Korean hotel industry and measures to overcome the crisis: A case study of six Korean five-star hotels. Asia Pacific Journal of Tourism Research, 10(4), 369-377.

Lane, B. (1994). What is rural tourism?. Journal of Sustainable Tourism, 2(1-2), 7-21.

Lane, B. (2009). Rural tourism: An overview, Chapter 21. In T. Jamal, \& M. Robinson (Eds.), The SAGE Handbook of Tourism Studies (pp. 354-370). London: Sage Publications.

Lane, B. (2020). Re-booting Tourism: Can Sustainable Tourism save the tourism world?, Bolzano, Italy. Eurac, 2020 for the Government of South Tyrol, Italy. Retrieved December 
20, 2020, from https://www.eurac.edu/en/blogs/covid-19/re-booting-tourism-cansustainable-tourism-save-the-tourism-world

Lane, B., \& Kastenholz, E. (2015). Rural tourism: the evolution of practice and research approaches - towards a new generation concept?. Journal of Sustainable Tourism, 23(8-9), 1133-1156.

Laws, E., Prideaux, B., \& Chon, K. (2007). Crisis management in tourism: Challenges for managers and researches. In E. Laws, B. Prideaux, \& K. Chon (Eds), Crisis Management in Tourism (pp. 1-12). Cambridge: Cab International.

Lew, A. (2014). Scale, change and resilience in community tourism planning. Tourism Geographies, 16(1), 14-22. doi: 10.1080/14616688.2013.864325

López-Guzmán, T., Vieira-Rodríguez, \& Rodríguez-García, J. (2014). Profile and motivations of European tourists on the Sherry wine route of Spain. Tourism Management Perspectives, 11, 63-68.

MacMillan, M. (2020, May 9). The world after covid-19. The Economist. Retrieved September 13, 2020, from https://www.economist.com/by-invitation/2020/05/09/margaretmacmillan-on-covid-19-as-a-turning-point-in-history

McManus, S., Seville, E., Vargo, J., \& Brunsdon, D. (2008). A facilitated process for improving organizational resilience. Natural Hazards Review, 9(2), 81-90.

Miles, M. B., Huberman, A. M., \& Saldana, J. (2014). Qualitative Data Analysis: A Methods Sourcebook. London: Sage.

Mohajan, H. (2018). Qualitative research methodology in social sciences and related subjects. Journal of Economic Development, Environment and People, 7(1), 23-48.

Moyle, B., Moyle, C., Ruhanen, L., Weaver, D., \& Hadinejad, A. (2020). Are we really progressing sustainable tourism research? A bibliometric analysis. Journal of Sustainable Tourism, 29(1), 106-122.

Nian, S., Zhang, J., Zhang, H., Zhang, J., Li, D., Wu, K., Chen, X., \& Yang, L. (2019). Two sides of a coin: A crisis response perspective on tourist community participation in a post-disaster environment. International Journal of Environmental Research and Public Health, 16(12), 2073-2092.

Oh, H., Assaf, A. G., \& Baloglu, S. (2016). Motivations and goals of slow tourism. Journal of Travel Research, 55(2), 205-219.

Organisation for Economic Co-operation and Development (OECD) (1994). Tourism Strategies and Rural Development. Retrieved December 20, 2020, from https://www.oecd.org/cfe/tourism/2755218.pdf

Page, S., Song, H., \& Wu, D. C. (2012). Assessing the impacts of the global economic crisis and swine flu on inbound tourism demand in the United Kingdom. Journal of Travel Research, 51(2), 142-153.

Paraskevas, A., \& Quek, M. (2019). When Castro seized the Hilton: Risk and crisis management lessons from the past. Tourism Management, 70, 419-429.

Pearson, C. M., \& Mitroff, I. I. (1993). From crisis prone to crisis prepared: A framework for crisis management. The Academy of Management Executive, 7(1), 48-59.

Pellin, V., \& Vieira, A.C.P. (2015). Contributions of geographical indications for territorial strengthening in rural space: A case study in southern Brazil. Espacios, 36(8), 7-7.

Pestana, M. H., \& Gageiro, J. N. (2008). Análise de Dados para Ciências Sociais [Data analysis in social sciences] (5a ed.). Lisboa: Edições Silabo.

Quadri-Felitti, D., \& Fiore, A. M. (2012). Experience economy constructs as a framework for understanding wine tourism. Journal of Vacation Marketing, 18(1), 3-15.

Rosenthal, U., Charles, M. T., \& Hart, P. (1989). The world of crises and crisis management. In U. Rosenthal, M. T. Charles, \& P. Hart (Eds.), Coping with crises: The management 
of disasters, riots and terrorism (pp. 3-33). Springfield: IL Charles C. Thomas.

Scaglione, M. (2007). Post-crisis forecasting: Better make haste slowly. In E. Laws, B. Prideaux, \& K. Chon (Eds.), Crisis Management in Tourism (pp. 13-31). Cambridge: Cab International.

Scott, D., Gössling, S., \& Hall, C. M. (2012). International tourism and climate change. WIREs Climate Change, 3, 213-232.

Selin, S. (1999) Developing a typology of sustainable tourism partnerships. Journal of Sustainable Tourism, 7(3-4), 260-273.

Semone, P. (2007). Preface: The Tsunami of 26 December 2005, PATA'S initial response. In E. Laws, B. Prideaux, \& K. Chon (Eds), Crisis Management in Tourism (pp. 13-18). Cambridge: Cab International.

Sharpley, R., \& Pearce, T. (2007). Tourism, marketing and sustainable development in the English national parks: The role of national park authorities. Journal of Sustainable Tourism, 15(5), 557-573.

Sidali, K. L., Kastenholz, E., \& Bianchi, R. (2015). Food tourism, niche markets and products in rural tourism: combining the intimacy model and the experience economy as a rural development strategy. Journal of Sustainable Tourism, 23(8-9), 1179-1197.

Sigala, M. (2020). Tourism and COVID-19: Impacts and implications for advancing and resetting industry and research. Journal of Business Research, 117, 312-321.

Stanford, D., \& Guiver, J. (2016). Driving pro-environmental change in tourist destinations: encouraging sustainable travel in National Parks via partnership project creation and implementation. Journal of Sustainable Tourism, 4(3), 484-505.

Statista. (2020a). Impact of the coronavirus pandemic on the global economy - Statistics \& Facts. Retrieved June 1, 2020, from https://www.statista.com/topics/6139/covid-19impact-on-the-global-economy/

Statista (2020b). Who's Most Vulnerable to COVID-19's Impact on Tourism? Retrieved June 1, 2020, from https://www.statista.com/chart/21391/total-contribution-of-travel-andtourism-to-gdp-of-selected-countries/

Statista (2020c). Coronavirus: impact on the tourism industry worldwide - Statistics \& Facts. Retrieved June 1, 2020, from https://www.statista.com/topics/6224/covid-19impact-on-the-tourism-industry/

Tsao, C., \& Ni, C. (2016). Vulnerability, resilience, and the adaptive cycle in a crisis-prone tourism community. Tourism Geographies, 18(1), 80105. doi: $10.1080 / 14616688.2015 .1116600$

WHO (2020a). QEA on coronaviruses (COVID-19). Retrieved June 1, 2020, from https://www.who.int/emergencies/diseases/novel-coronavirus-2019/questionand-answers-hub/q-a-detail/q-a-coronaviruses

WHO (2020b). WHO Timeline - COVID-19. Retrieved June 1, 2020, from https://www.who.int/news-room/detail/27-04-2020-who-timeline---covid-19

WHO (2020c). Coronavirus disease (COVID-19) advice for the public. Retrieved June 1, 2020, from https://www.who.int/emergencies/diseases/novel-coronavirus-2019/advicefor-public

Ye, B. H., Zhang, H. Q., \& Yuan, J. (2017). Intentions to participate in wine tourism in an emerging market: Theorization and implications. Journal of Hospitality and Tourism Research, 41(8), 1007-1031.

Zeng, B., Carter, R. W., \& De Lacy, T. (2005). Short-term perturbations and tourism effects: The case of SARS in China. Current Issues in Tourism, 8(4), 306-322.

Zenker, S., \& Kock, F. (2020). The coronavirus pandemic - A critical discussion of a tourism research agenda. Tourism Management, 81, 1-4 